\title{
First insights into micromorphology of needle epicuticular waxes of south-eastern european Pinus nigra J. F. Arnold populations
}

\author{
Zorica S. Mitić ${ }^{1}$, Bojan K. Zlatković ${ }^{1}$, Miroslav S. Miljković², Snežana Č. Jovanović ${ }^{3}$, \\ Petar D. Marin ${ }^{4}$ \& Gordana S. Stojanović ${ }^{3}$
}

\author{
University of Niš, Faculty of Sciences and Mathematics, Department of Biology and Ecology, \\ Višegradska 33, 18000 Niš, Serbia. saraczorica@gmail.com \\ 2 University of Niš, Faculty of Medicine, Laboratory for Electron Microscopy, Boulevard Dr Zorana Đinđića 81, \\ 18000 Niš, Serbia. miroslav.milljkovic@medfak.ni.ac.rs \\ ${ }^{3}$ University of Niš, Faculty of Sciences and Mathematics, Department of Chemistry, Višegradska 33, 18000 Niš, Serbia. gocast@pmf.ni.ac.rs \\ ${ }^{4}$ University of Belgrade, Faculty of Biology, Institute of Botany and Botanical Garden "Jevremovac", \\ Studentski trg 16, 11000 Belgrade, Serbia. pdmarin@bio.bg.ac.rs
}

Received on 30.1.2016

Accepted on 01.XI.2017

DOI 10.21826/2446-8231201772306

\begin{abstract}
This is the first insight into the fine structure of the epicuticular wax crystalloids found on the adaxial surfaces of needles from three Pinus nigra subspecies (ssp. nigra, ssp. banatica (Borbás) Novák, and ssp. pallasiana (Lamb.) Holmboe) growing wild in the south-eastern Europe. In general, the main wax crystalloids in $P$. nigra taxa were tubules, fairly dense, with reticular aspect and restricted to suprastomatal chambers. The P. nigra needles have amorphous wax - smooth layers, granules, alone tubes lying on the surface, tubes slightly fused to each other, tubes fused together, and longitudinally aggregated rodlets. The only difference between the studied $P$. nigra samples was related to the presence of longitudinally aggregated rodlets in the medial part of adaxial needle surfaces. The micromorphological characters found using SEM are compared and discussed from fundamental and applicative aspects.
\end{abstract}

Keywords: crystalline tubules, longitudinally aggregated rodlets

RESUMO - Primeiros conhecimentos sobre a micromorfología das ceras epicuticulares de agulhas de populações de Pinus nigra J. F. Arnold do sudeste da Europa. Este é o primeiro estudo sobre a estrutura fina dos cristalóides de cera epicuticular, que se encontram na superfície adaxial de agulhas de três subespécies de Pinus nigra (ssp. nigra, ssp. banatica e ssp. pallasiana) silvestres do sudeste de Europa. Em geral, a maioria dos cristalóides de ceras nos táxons de $P$. nigra são túbulos, bastante densos, com aspecto reticulares e restringidos às câmaras supraestomáticas. As agulhas de P. nigra possuem cera amorfa, capas lisas, grânulos, tubos isolados localizados na superfície, tubos levemente fusionados entre si, tubos fusionados e rodlets agregados longitudinalmente. A única diferença entre as amostras estudadas de $P$. nigra foi a presença de rodlets agregados longitudinalmente na parte medial da superfície adaxial das agulhas. Os caracteres micromorfológicos encontrados, utilizando SEM, têm sido comparados e discutidos desde aspectos fundamentais e aplicáveis.

Palavras-chave: túbulos cristalinos, rodlets agregados longitudinalmente

\section{INTRODUCTION}

The plant cuticle is an extracellular lipid structure deposited over the aerial surfaces of land plants, sealing the shoot and protecting it from biotic and abiotic stresses (Kunst $\&$ Samuels 2009). It consists of amorphous intracuticular wax embedded in cutin polymer and epicuticular wax film with distinct projections i.e. crystalloids of high structural diversity. Specifically, numerous examinations by SEM (Scanning Electron Microscope) have shown that most epicuticular waxes form three-dimensional structures (crystalloids) with large variations in their morphologies (reviewed in Koch et al. 2008). These local wax projections, usually with a characteristic shape, size, and orientation towards the surface, protrude from the ubiquitous epicuticular wax film which can hardly be detected by SEM
(Barthlott et al. 1998). Detailed overviews on classification and terminology of plant epicuticular waxes were published by Metcalfe \& Chalk (1979), Barthlott et al. (1998) and Jeffree (2006). The classification according to Barthlott et al. (1998) recognized the greatest number (23) of wax types, taking into account chemical and morphological features as well as orientation and pattern of the wax structures. On the other hand, seven and six wax types were classified by Metcalfe \& Chalk (1979) and Jeffree (2006), respectively. It is noteworthy that, wax structures found on leaves have been more intensively investigated and characterized than those found on other plant organs (Tomaszewski \& Zieliński 2014).

In general, previous SEM studies have revealed an extraordinary variability of epicuticular wax structure and patterns (Barthlott et al. 1990, Koch et al. 2008, 
Tomaszewski \& Zieliński 2014). According to Barthlott et al. $(1990,1996,2003)$, these characters are surprisingly little affected by the environmental conditions in which plants grow and thus have been used for systematic purposes. At the same time, many authors have suggested that air pollutants or acid precipitation may alter the structure and/ or composition of cuticular waxes, thereby increasing both the uptake of harmful substances and the loss of nutrient ions (Cape 1986, Sauter \& Voss 1986, Riederer 1989, Percy \& Baker 1990). However, physical properties of plant cuticle are determined by its chemical composition and fine structure, which must be understood before the effects of air pollutants can be analyzed.

In conifers, SEM studies of epicuticular waxes have mainly been focused on influence of different pollutants on their structure (Crossley \& Fowler 1986, Bermadinger et al. 1987, Kupčinskienė 1999, Ivănescu et al. 2008, Burkhardt \& Pariyar 2014). For instance, Tuomisto (1988) analyzed use of needles of Picea abies (L.) H.Karst. as indicators of air pollution from the viewpoint of the micromorphology of epicuticular waxes. It proposed a very detail classification of the wax structural forms recognizing 11 micromorphological types on P. abies needles. On the other hand, there is a lack of systematic studies where the micromorphology of epicuticular wax crystalloids has been analyzed for a group of related conifer taxa. However, it is important to note that, like all taxonomic criteria, these characters should be interpreted with great caution, considering that although the huge number of SEM micrographs has been published, much of the data is not comparable to each other, due to different standard terminologies and often no structural interpretation of the characters illustrated (Barthlott et al. 1990).

Pinus nigra J.F. Arnold (European black pine) is a Tertiary relict species from the Pinaceae family and one of the most widespread and polymorphic conifers in Europe (Gaussen et al. 1993). In accordance with the geographical and ecological diversity of its habitats and its disjunctive distribution the black pine is an extremely variable species (Vidaković 1991). Due to the high morphological polymorphism throughout the range, its taxonomic status and infraspecific classification are still somewhat unclear (e.g. Vidaković 1991, Gaussen et al. 1993, see also references in Naydenov et al. 2006 and Ganopoulos et al. 2013). Several infraspecific taxa are recognized within the Southern Carpathians and central Balkan Peninsula, and their relationships are yet to be investigated (reviewed in Boşcaiu \& Boşcaiu 1999, Šarac et al. 2013, 2014, 2015).

Thus, the objective of the present work was to investigate the epicuticular wax types found on the adaxial surfaces of nine needle samples from three $P$. nigra subspecies (ssp. nigra, ssp. banatica (Borbás) Novák, and ssp. pallasiana (Lamb.) Holmboe), growing wild in Bosnia and Herzegovina, Romania, Serbia, and Macedonia. The micromorphological characters found using SEM are compared and discussed from fundamental and applicative aspects.

\section{MATERIAL AND METHODS}

\section{Plant material}

Samples ( 2 to 3 year-old needles) were collected in midsummer 2013 from one tree per population from 9 native populations belonging to different infraspecific taxa of P. nigra (determined as ssp. banatica, ssp. pallasiana, and ssp. nigra) growing wild in the southern Carpathians and the central Balkans, viz., P. nigra ssp. banatica was represented by four populations: I (Romania, Mt. Domogled), II (Romania, Svinita), III (Serbia, Lazareva Reka Canyon), and IV (Serbia, Jerma Canyon); P. nigra ssp. pallasiana by three populations: V (Serbia, Mt. Dukat), VI (Macedonia, Mt. Kožuf), and VII (Macedonia, Strumica); and P. nigra ssp. nigra by two populations: VIII (Serbia, Mileševka Canyon) and IX (Bosnia and Herzegovina, Mt. Orijen). From each population, one additional sample was deposited in the Herbarium of the Institute of Botany and Botanical Garden "Jevremovac", Faculty of Biology, University of Belgrade (BEOU) and the Herbarium of the Department of Biology and Ecology, Faculty of Sciences and Mathematics, University of Niš (HMN). Locations of selected populations are presented in Figure 1, and details regarding places of collection and characteristics of sampling localities are listed in the Table 1.

\section{Scanning electron microscopy}

To examine the micromorphology of epicuticular waxes, the needle surface moisture was allowed to evaporate for the same amount of time, as many researchers used air-dried samples in order to preserve and dehydrate needles for wax morphology studies while solvents used in standard SEM preparative procedures could remove or alter epicuticular wax and salt crystal distribution (Bermadinger et al. 1987, Tuomisto \& Neuvonen 1993, Kupčinskienė 1999). After air-drying, the nine needle samples (one needle per studied population) were mounted sequentially on specimen stubs sputter-coated with gold and examined with JEOL JSM 5300 scanning electron microscope. Representative areas of adaxial surface of each needle were photographed at magnifications in the range of $50 \mathrm{x}-5.000 \mathrm{x}$. However, the adaxial surfaces of only three samples (from each $P$. nigra subspecies) are illustrated (Fig. 2), which were selected to show the evident range of micromorphological variations as explained below.

\section{RESULTS AND DISCUSSION}

Medial part of adaxial needle surfaces collected from all nine P. nigra populations indicated the presence of stomata arranged in parallel and uniseriate bands, while the margin areas were serrated with mucrones pointing toward the tip of the leaf (saw-tooth margins) (Figs. 1A and 1B). In general, the main wax crystalloids in P. nigra taxa were tubules, fairly dense, with reticular aspect and restricted to suprastomatal chambers (Fig. 2E). Namely, the tubule regions were absent from the larger areas of 


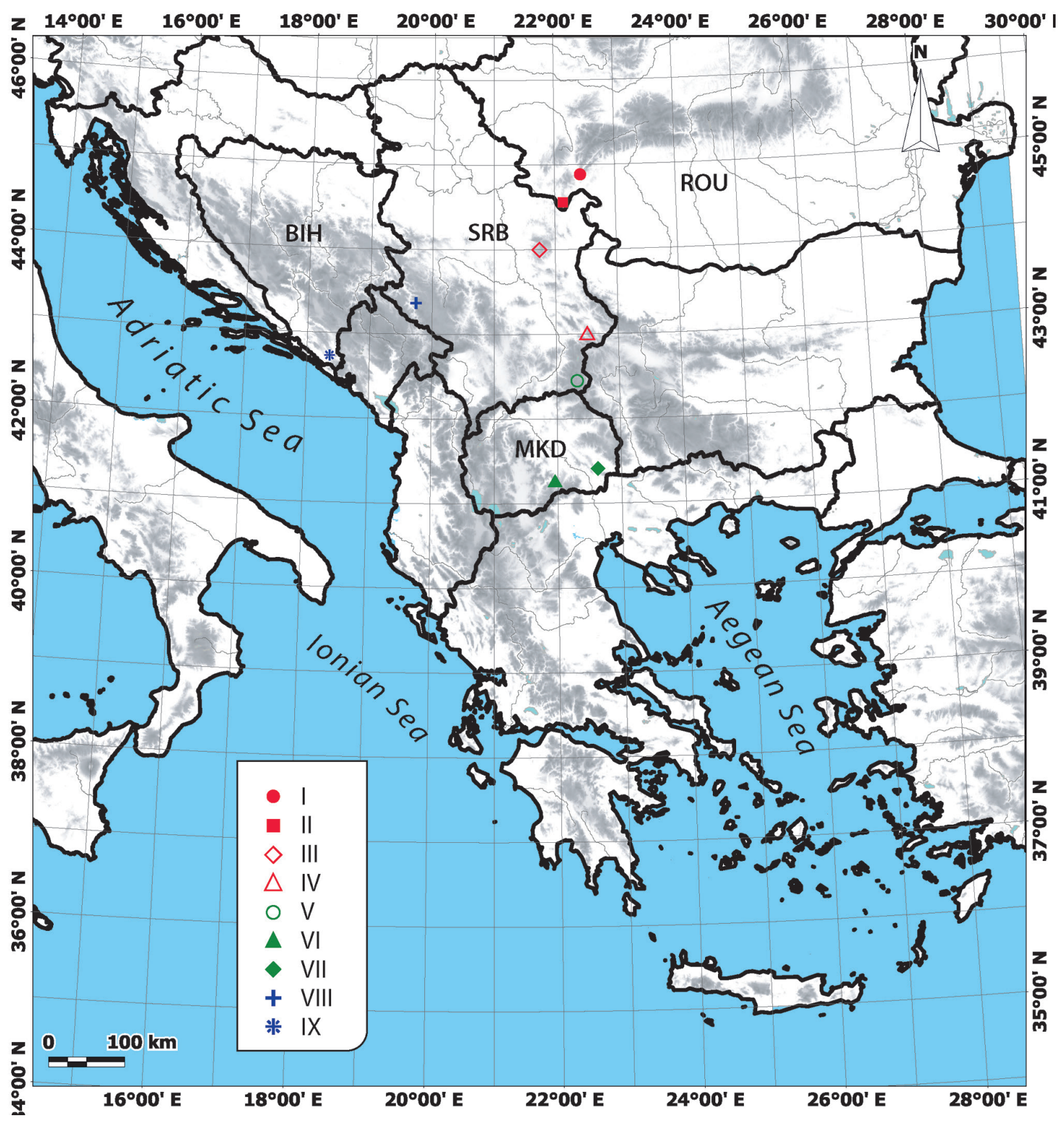

Fig. 1. Location of analyzed south-eastern European populations of three P. nigra subspecies. P. nigra ssp. banatica (Populations I-IV), P. nigra ssp. pallasiana (Populations V-VII), and P. nigra ssp. nigra (Populations VIII and IX). ROU = Romania; SRB = Serbia; MKD = Macedonia; BIH $=$ Bosnia and Herzegovina. For the description of the taxa, locations, and habitat conditions of the populations cf. Table 1.

the stomatal bands, but still maintained on the raised suprastomatal chamber surrounding and filling them (Fig. 2D). The remaining surfaces of stomatal bands as well as interstomatal areas appeared as continuous coverings without a prominent surface sculpturing, i.e. smooth layers, but in some places with noticeable granules (Figs. 2C, D). However, according to Barthlott et al. (1998), it is doubtful whether granules are crystals, considering that in many cases contaminants were misinterpreted as granules and vice versa. Moreover, it is important to note that the epicuticular waxes of coniferous needles change their appearance as part of the natural ageing process: within one year after needle elongation the wax tubules begin to fuse together and form a net-like structure, but gradually all structural wax degrades to granules or an amorphous crust (natural weathering). In addition, the weathering of the wax could be remarkably enhanced by mechanical abrasion and wind damage or by chemical interaction with pollutants (Crossley \& Fowler 1986).

Many studies have shown that in Pinales, wax tubules on needles are not distributed evenly, considering their tendency to be concentrated near stomata and between 
Table 1. The infraspecific taxa of Pinus nigra used in the present study: places of collection, characteristics of sampling localities, and micromorphological types of epicuticular waxes according by Tuomisto (1988), Barthlott et al. (1998) and Jeffree (2006). SL= smooth layers (cover the largest area of needles); GR = granules (randomly distributed in interstomatal and stomatal areas); AT =alone tubes lying on the surface (concentrated near stomata); $\mathrm{TSF}=$ tubes slightly fused to each other (suprastomatal chambers and their close surroundings); TF = tubes fused together (suprastomatal chambers); $\mathrm{LAR}=$ longitudinally aggregated rodlets (randomly distributed in interstomatal interstomatal areas).

\begin{tabular}{|c|c|c|c|c|c|c|}
\hline P. nigra subspecies & Locality & $\begin{array}{l}\text { Population } \\
\text { code }\end{array}$ & Latitude $(\mathrm{N})$ & Longitude (E) & $\begin{array}{l}\text { Altitude } \\
\text { (m a.s.1.) }\end{array}$ & $\begin{array}{l}\text { Micromorphological types of } \\
\text { epicuticular waxes }\end{array}$ \\
\hline \multirow{4}{*}{ ssp. banatica } & $\begin{array}{l}\text { Romania: Mt. } \\
\text { Domogled, the } \\
\text { Cerna Valley }\end{array}$ & I & $44^{\circ} 52^{\prime} 52.68^{\prime \prime}$ & $22^{\circ} 25^{\prime} 39.32^{\prime \prime}$ & 670 & SL, GR, TSF \\
\hline & $\begin{array}{c}\text { Romania: Svinita, } \\
\text { the Danube } \\
\text { Valley }\end{array}$ & II & $44^{\circ} 29^{\prime} 00.16^{\prime \prime}$ & $22^{\circ} 08^{\prime} 35.58^{\prime \prime}$ & 180 & SL, GR, AT, TSF, LAR \\
\hline & $\begin{array}{c}\text { Serbia: Lazareva } \\
\text { Reka Canyon, } \\
\text { Kovej }\end{array}$ & III & $44^{\circ} 0 ’ 47.05^{\prime}$ & $21^{\circ} 55^{\prime} 15.27^{\prime \prime}$ & 698 & $\mathrm{SL}, \mathrm{GR}, \mathrm{TF}$ \\
\hline & $\begin{array}{l}\text { Serbia: Jerma } \\
\text { Canyon, Tikva }\end{array}$ & IV & $42^{\circ} 58^{\prime} 35.14^{\prime \prime}$ & $22^{\circ} 37^{\prime} 22.63^{\prime \prime}$ & 694 & $\mathrm{SL}, \mathrm{GR}, \mathrm{TF}$ \\
\hline \multirow{3}{*}{ ssp. pallasiana } & $\begin{array}{c}\text { Serbia: Mt. } \\
\text { Dukat, Jarešnik }\end{array}$ & $\mathrm{V}$ & $42^{\circ} 24^{\prime} 7.25^{\prime \prime}$ & $22^{\circ} 23^{\prime} 25.12^{\prime \prime}$ & 1440 & $\mathrm{SL}, \mathrm{GR}, \mathrm{TF}$ \\
\hline & $\begin{array}{l}\text { Macedonia: Mt. } \\
\text { Kožuf, Mrežičko- } \\
\text { Rožden }\end{array}$ & VI & $41^{\circ} 11^{\prime} 58.72^{\prime \prime}$ & $21^{\circ} 58^{\prime} 31.17^{\prime \prime}$ & 577 & SL, GR, TSF \\
\hline & $\begin{array}{l}\text { Macedonia: } \\
\text { Strumica, Tri } \\
\text { Vodi }\end{array}$ & VII & $41^{\circ} 24^{\prime} 36.00^{\prime \prime}$ & $22^{\circ} 37^{\prime} 38.00^{\prime \prime}$ & 320 & SL, GR, AT, TSF, LAR \\
\hline \multirow[b]{2}{*}{ ssp. nigra } & $\begin{array}{c}\text { Serbia: Prijepolje, } \\
\text { Mileševka } \\
\text { Canyon }\end{array}$ & VIII & $43^{\circ} 21^{\prime} 23.72^{\prime \prime}$ & $19^{\circ} 45^{\prime} 13.62 ”$ & 853 & $\mathrm{SL}, \mathrm{GR}, \mathrm{TF}$ \\
\hline & $\begin{array}{c}\text { Bosnia and } \\
\text { Herzegovina: } \\
\text { Mt. Bijela Gora, } \\
\text { Aranđelovo }\end{array}$ & IX & $42^{\circ} 41^{\prime} 59.27^{\prime \prime}$ & $18^{\circ} 31^{\prime} 57.65^{\prime \prime}$ & 379 & $\mathrm{SL}, \mathrm{GR}, \mathrm{TF}$ \\
\hline
\end{tabular}

them in the stomatal rows (Crossley \& Fowler 1986, Kim et al. 2011, Ivănescu et al. 2008). On the other hand, it is interesting that the situation may look entirely different on conifer stems. For example, tubules are found only near stomata on needles of Abies pinsapo Boiss., while on stems they are more or less evenly distributed (Tomaszewski \& Zieliński 2014).

Though the epicuticular wax crystalloids appeared as rodlets in the micrographs presented here (Fig. 2E), this was probably an artifact considering that the sputter coating technique used would probably have obscured the terminal opening of a tubular crystal form (Crossley \& Fowler 1986). Moreover, it has been reported that the wax crystals of conifer needles are mainly tubular and characterized by dominance of secondary alcohol nonacosan-10-ol (socalled nonacosanol-tubules, Riederer 1989, Barthlott et al. 1998). Nonacosan-10-ol is a dominant compound in the epicuticular leaf waxes of many gymnosperm genera (Gingko, Pinus, Abies, Picea, Wollemia, Taxus etc.) as well as of some angiosperms, and it is largely responsible for the tubular microstructure of the leaf surface (Jeffree 2006).

Although the chemical composition of the different crystalloids types generally refers to the dominant component of the bulk wax, the ability of nonacosanol-10-ol to recrystallize in-vitro as tubules has been demonstrated in several investigations (Jeffree et al. 1975, Jetter \& Riederer 1994, Ensikat et al. 2006). However, to the best of the authors' knowledge, the contents and variability of nonacosanol-10-ol in the needle waxes of P. nigra populations have not yet been studied. The composition of epicuticular waxes of this species has been addressed only regarding the contents of n-alkanes (Maffei et al. 2004, Bojović et al. 2012) or n-alkanes and primary alcohols (Mitić et al. 2016).

It's worth noting that randomly distributed wax structures were also noticed in the medial part of adaxial needle surfaces of two $P$. nigra samples (from populations II and VII) (Fig. 2A). At high magnification (750x and $1.000 \mathrm{x}$ ) these structures appeared as clusters consisting of longitudinally aggregated rodlets, i.e. rodlets fused together along their longitudinally axes (Table 1, Fig. 2C). However, we noticed that these assemblages of crystalloids were better preserved in population II (ssp. banatica), while in population VII (ssp. pallasiana) they were mostly fused into an amorphous surface (Fig. 2C). Considering that only one needle per population was included in the present study, it could not be determined if the presence and abundance of these crystalloids in black pine populations 

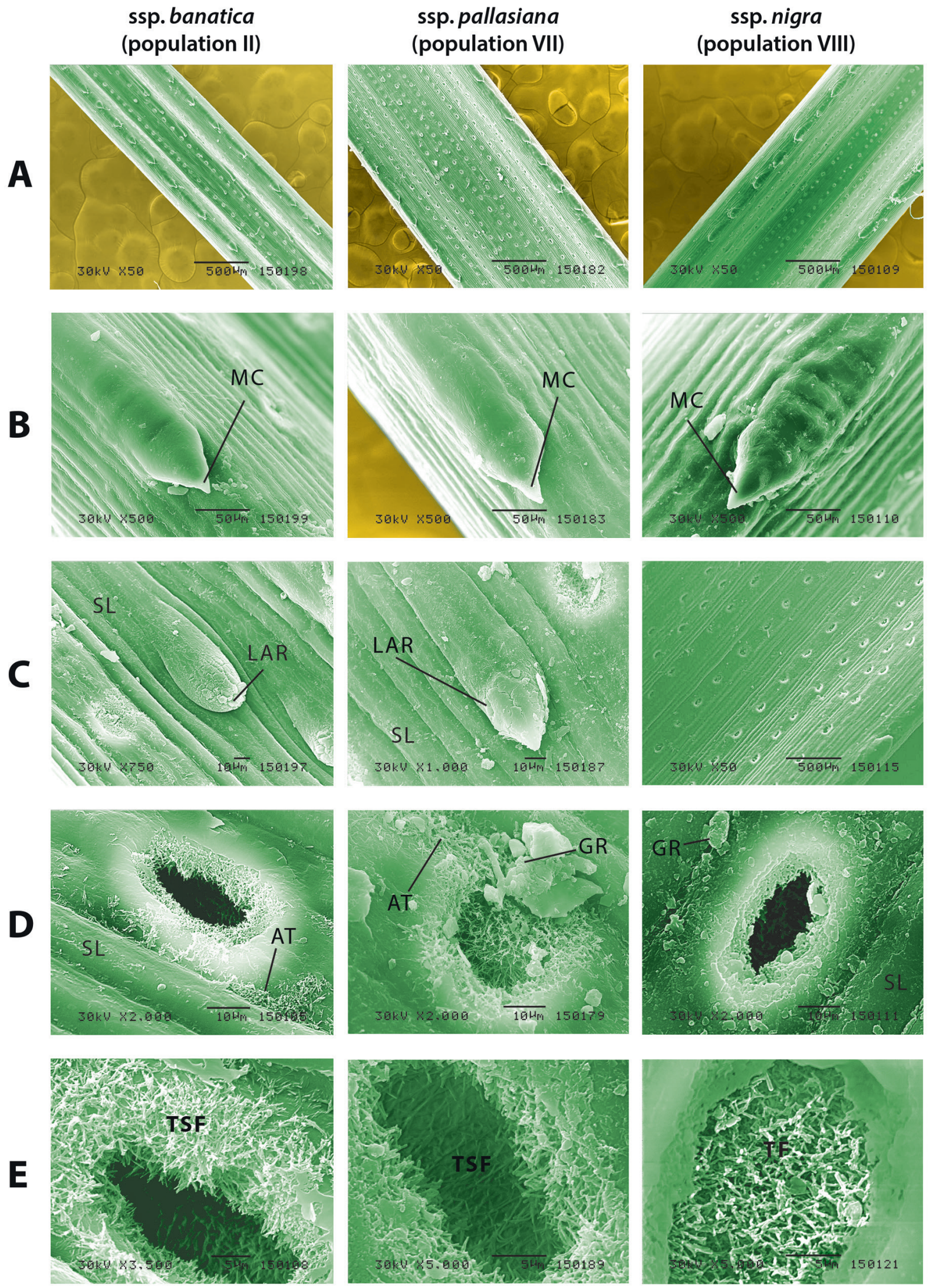

Fig. 2. SEM micrographs of $P$. nigra epicuticular waxes. A. adaxial surface of needles; B. marginal teeth with mucrones (MC); C. clusters of longitudinally aggregated rodlets (LAR); D. suprastomatal chambers surrounded by alone tubes lying on the surface (AT) as well as individual granules (GR); E. tubes slightly fused to each other (TSF) and tubes fused together (TF), which surround and fill the suprastomatal chambers; smooth layers (SL - amorphous wax that covers the largest area of needles). 
might be used as taxonomic markers to delineate $P$. nigra infraspecific taxa. Furthermore, the presence of massive longitudinally furrowed rodlets in Pinus spp. had to be regarded as convergent as this arrangement of crystalloids was also discovered within monocotyledon subclasses Arecidae, Zingiberidae and Commelinidae (Barthlott et al. 1998).

With respect to wax classifications proposed by Tuomisto (1988), Barthlott et al. (1998) and Jeffree (2006), the following micromorphological types of wax on $P$. nigra needles were noticed in this work (Table 1, Fig. 2): amorphous wax - smooth layers (SL), granules (GR), alone tubes lying on the surface (AT), tubes slightly fused to each other (TSF), tubes fused together (TF), and longitudinally aggregated rodlets (LAR). Similar result was reported for P. sylvestris L. by Kupčinskienè (1999), who detected 7-9 micromorphological forms on the needle surface including two separate classes of amorphous wax (even and uneven amorphous wax). On the other hand, higher number of separate wax forms recognized on Picea abies needles (11 micromorphological types; Tuomisto 1988) might have appeared owing to differences in species-dependent specificity of structural wax distribution: Picea abies needles have protective tubular wax architecture all over the surface, whereas in Pinus nigra and P. sylvestris they appear only in the stomatal rows (Huttunen 1994).

Future research should be focused on estimating of abundance of each type of the wax crystalloids on the needle surface as well as their intra- and inter-population variability in order to determine ecological and genetic influence on micromorphology of epicuticular waxes and, therefore, possible usefulness of these characters in the infraspecific classification of Pinus nigra.

\section{ACKNOWLEDGEMENTS}

This research was supported by grants (173029 and 172047) by the Ministry of Education, Science and Technological Development of the Republic of Serbia. The authors would like to thank Sretko Milanović and Branko Jotić for help in collection of plant material.

\section{REFERENCES}

Barthlott, W. 1990. Scanning electron microscopy of the epidermal surface in plants. In Scanning Electron Microscopy in Taxonomy and Functional Morphology (D. Claugher, ed.). Clarendon Press, Oxford, p. 69-94.

Barthlott, W., Neinhuis, C., Cutler, D., Ditsch, F., Meusel, I., Theisen, I. \& Wilhelmi, H. 1998. Classification and terminology of plant epicuticular waxes. Botanical Journal of the Linnean Society 126:237260.

Barthlott, W., Neinhuis, C., Jetter, R., Bourauel, T. \& Riederer, M. 1996. Waterlily, poppy, or sycamore: on the systematic position of Nelumbo. Flora 191:169-174.

Barthlott, W., Theisen, I., Borsch, T. \& Neinhuis, C. 2003. Epicuticular waxes and vascular plant systematics: Integrating micromorphological and chemical data. In Deep morphology: toward a renaissance of morphology in plant systematic (T.F. Stuessy, V. Mayer \& E. Hörandl, eds.). Ruggell, Liechtenstein, p. 189-206.
Bermadinger, E., Grill, D. \& Golob, P. 1987. The different influence of magnesite emissions on the surface waxes of Norway spruce and silver fir. Canadian Journal of Botany 66:125-129.

Bojović, S., Šarac, Z., Nikolić, B., Tešević, V., Todosijević, M., Veljić, M. \& Marin, P.D. 2012. Composition of n-alkanes in natural populations of Pinus nigra from Serbia - chemotaxonomic implications. Chemistry \& Biodiversity 9:2761-2774.

Boşcaiu, N. \& Boşcaiu, M. 1999. On the presence of Pinus nigra subsp. pallasiana in Romania. Wissenschaftliche Mitteilungen Niederösterreichisches Landesmuseum 12:21-24.

Burkhardt, J. \& Pariyar, S. 2014. Particulate pollutants are capable to 'degrade' epicuticular waxes and to decrease the drought tolerance of Scots pine (Pinus sylvestris L.). Environmental Pollution 184:659667.

Cape, J.N. 1986. Effects of air pollution on the chemistry of surface waxes of Scots pine. Water, Air, \& Soil Pollution 31:393-399.

Crossley, A. \& Fowler, D. 1986. The weathering of Scots pine epicuticular wax in polluted and clean air. New Phytologist 103:207-218.

Ensikat, H.J., Boese, M., Mader, W., Barthlott, W. \& Koch, K. 2006. Crystallinity of plant epicuticular waxes: electron and X-ray diffraction studies. Chemistry and Physics of Lipids 144:45-59.

Ganopoulos, I., Aravanopoulos, F., Madesis, P., Pasentsis, K., Bosmali, I., Ouzounis, C. \& Tsaftaris, A. 2013. Taxonomic identification of Mediterranean pines and their hybrids based on the high resolution melting (HRM) and trnL approaches: from cytoplasmic inheritance to timber tracing. PLoS ONE 8:e60945.

Gaussen, H., Heywood, V.H. \& Charter, A.O. 1993. Pinus L. In Flora Europaea 1 (T.G. Tutin, N.A. Burges, A.O. Chater, J.R. Edmondson, V.H. Heywood, D.M. Moore, D.H. Valentine, S.M. Walters \& D.A. Webb, eds.). Cambridge University Press, Cambridge, p. 40-44.

Huttunen, S. 1994. Effects of air pollutants on epicuticular wax structure. In Air pollutants and the leaf cuticle (K.E. Percy, J.N. Cape, R. Jagels \& C.J. Simpson, eds.). Springer-Verlag (Series G: Ecological Sciences), Heidelberg, v. 36, p. 82-96.

Ivănescu, L., Toma, C., Zamfirache, M.M. \& Galeş, R.C. 2008. Some aspects concerning the interaction between needle surfaces and solid industrial pollutants. Studia Universitatis "Vasile Goldiş", Seria Ştiințele Vieții (Life Sciences Series) 18:275-280.

Jeffree, C.E. 2006. The fine structure of the plant cuticle. In Biology of the plant cuticle (M. Riederer \& C. Müller, eds.). Blackwell, Oxford, p. 11-125.

Jeffree, C.E., Baker, E.A. \& Holloway, P.J. 1975. Ultrastructure and recrystallisation of plant epicuticular waxes. New Phytologist 75:539-549.

Jetter, R. \& Riederer, M. 1994. Epicuticular crystals of nonacosan-10-ol: in vitro reconstitution and factors influencing crystal habits. Planta 195:25-270.

Kim, K.W., Lee, I.J., Kim, C.S., Lee, D.K. \& Park, E.W. 2011. Micromorphology of epicuticular waxes and epistomatal chambers of pine species by electron microscopy and white light scanning interferometry. Microscopy and Microanalysis 17:118-124.

Koch, K., Bhushan, B. \& Barthlott, W. 2008. Diversity of structure, morphology and wetting of plant surfaces. Soft Matter 4:1943-1963.

Kunst, L. \& Samuels, L. 2009. Plant cuticles shine: advances in wax biosynthesis and export. Current Opinion in Plant Biology 12:721727.

Kupčinskienè, E. 1999. Surface structures of Pinus sylvestris needles under the influence of low-level industrial emissions. Baltic Forestry 5:20-31.

Maffei, M., Badino, S. \& Rossi, S. 2004. Chemotaxonomic significance of leaf wax n-alkanes in the Pinales (Coniferales). Journal of Biological Research 1:3-19.

Metcalfe, C.R. \& Chalk, L. 1979. Anatomy of the dicotyledons, v.1. Clarendon Press, Oxford. 297 p.

Mitić, Z.S., Zlatković, B.K., Jovanović, S.Č., Stojanović, G.S. \& Marin, P.D. 2016. Geographically related variation in epicuticular wax traits of Pinus nigra populations from Southern Carpathians and Central Balkans - taxonomic considerations. Chemistry \& Biodiversity 13:1-12.

Naydenov, K.D., Tremblay, F., Fenton, N. \& Alexandrov, A. 2006. Structure of Pinus nigra Arn. populations in Bulgaria revealed by chloroplast microsatellites and terpenes analysis: Provenance tests. Biochemical Systematics and Ecology 34:562-574. 
Percy, K.E. \& Baker, E.A. 1990. Effects of simulated acid rain on epicuticular wax production, morphology, chemical composition and on cuticular membrane thickness in two clones of Sitka spruce [Picea sitchensis (Bong.) Carr.]. New Phytologist 116:79-87.

Riederer, M. 1989. The cuticles of conifers: structures, composition and transport properties. In Ecological studies (E.D. Schulze, O.L. Lange \& R. Oren, eds.). Springer, Berlin, p. 157-192.

Šarac, Z., Bojović, S., Nikolić, B., Tešević, V., Đorđević, I. \& Marin, P.D. 2013. Chemotaxonomic significance of the terpene composition in natural populations of Pinus nigra J. F. Arnold from Serbia. Chemistry \& Biodiversity 10:1507-1520.

Šarac, Z., Bojović, S., Nikolić, B., Zlatković, B. \& Marin, P.D. 2014. Application of canonical discriminant analysis in differentiation of natural populations of Pinus nigra in Serbia based on terpene composition. Biologica Nyssana 5:11-15.

Šarac, Z., Dodoš, T., Rajčević, N., Bojović, S., Marin, P.D. \& Aleksić, J.M. 2015. Genetic patterns in Pinus nigra from the central Balkans inferred from plastid and mitochondrial data. Silva Fennica 49(5). https://doi.org/10.14214/sf.1415.

Sauter, J.J. \& Voss, U. 1986. SEM-observations on the structural degradation of epistomatal waxes in Picea abies (L.) Karst. and its possible role in the "Fichtensterben". European Journal of Plant Pathology 16:408-423.

Tomaszewski, D. \& Zieliński, J. 2014. Epicuticular wax structures on stems and comparison between stems and leaves - a survey. Flora 209:215-232

Tuomisto, H. 1988. Use of Picea abies needles as indicators of air pollution: epicuticular wax morphology. Annales Botanici Fennici 23:351-364.

Tuomisto, H. \& Neuvonen, S. 1993. How to quantify differences in epicuticular wax morphology of Picea abies L. Karst. needles. New Phytologist 123:787-799.

Vidaković, M. 1991. Conifers. Morphology and variation. Grafički Zavod Hrvatske, Zagreb. 754 p. 